\title{
Transformative Digital Learning in the Context of Higher Education: Definition and Basic Concepts
}

\author{
Olga Vindaca ${ }^{1}$ Mg.paed.; Velta Lubkina ${ }^{2}$ Dr.paed. \\ Rezekne Academy of Technologies, Latvia \\ olgavindacha@inbox.lv; velta.lubkina@rta.lv²
}

\begin{abstract}
Transformative digital learning is associated with qualitative changes in educational work. It is important to each individual in order to live and work productively in a changing digitalized world, to continue education throughout life. Despite of the growing interest in the digitalization and transformation phenomenon parties involved are not able to concisely spot the connection and difference between the digital learning, digital transformation and transformative learning, as well as to formulate the definition of transformative digital learning. This article is based on the theoretical research in the field of transformative digital learning in the context of higher education. The aim of this paper to review the literature about the topic and by analysing different explanations and approaches to formulate the definition of transformative digital learning in three dimensions as digital learning, digital transformation and transformative learning. A literature review about the transformative digital learning in the context of higher education was made, basing on the analyses the definition was developed and basic concepts listed. The research results offer theoretical implications for the definition of transformative digital learning in the context of higher education.
\end{abstract}

Keywords: digital transformation, transformative digital learning, higher education.

\section{Introduction}

School year 2019/2020 has been named as the Technology Year in Latvia by Ministry of Education and Science enabling a variety of information technology activities for students, educators and the public (Jauno mācību gadu..., 2019)

Based on multidimensional survey summarized by A. Visvizi, M.D. Lytras, L. Daniela the future perspectives of innovation and technology in education include the idea that the field of education is not immune to advances in sophisticated information and communication technology, hence it can serve as supportive educational tool. Most important, by creating modern learning field, three key elements should be included: pedagogy, environment and technologies. This is a challenging problem for everyone involved into the education process. Today, technology enables a significant expansion of the learning environment, providing learning opportunities at any time and place. Digitalization offers tremendous opportunities for innovation, growth and employment, contributes to the global competitiveness of people and enhances creativity and cultural diversity (Visvizi, Lytras, Daniela, 2018).

It is important to understand the difference between the definitions as digital learning, digital transformation, transformative digital learning, as these are not just the same. Despite of the growing interest in the digitalization and transformation phenomenon parties involved are not able to provide the detailed explanation and connection between the transformative learning and digitalization. After analysing the abstract and citation databases like EBSCO there is no exact matching for the term transformative digital learning. Moreover, there are 11544 records concerning digital learning and 7176 records for transformative learning. If to speak about transformative learning the articles were published starting from 1978 year when J. Mezirow's transformative learning theory has been developed. In turn of digital learning the first articles are dated of 1961 year when the adoption and proliferation of digital computer we adopted.

At the same time, as of 12th of November 2019 a Google search returned more than 22 million hits for the term of transformative digital learning, reflecting also changing algorithm of the indicated words by changing word order. Because of this to formulate the definition of transformative digital learning in the context of higher education the concepts of digital learning, digital transformation and transformative learning were analysed. 
The aim of this paper to review the literature about the topic and by analysing different explanations and approaches to formulate the definition of transformative digital learning (TDL) in three dimensions as digital learning, digital transformation and transformative learning.

\section{Methodology}

The research undertaken for this study is theoretical and based on a study and overview of the existing literature in the topic. Within the scope of the research the literature consulted includes articles specifically on digital learning (Kyndt et al., 2009; Gonḉalves, Sousa, Cruz, 2017; Sousa, Rocha, 2019a), digital transformation (Filho et al., 2018; Mergel, Edelmann, Haug, 2019) transformative learning (Boyd, Myers, 1988; Mezirow, 1999; Henderson, 2002; Taylor, 2007; Cranton, 2009; Dirkx, 1997; Howie, Bagnall, 2013; Christie et al., 2015) and transformative digital learning (Mykhailenko et al., 2018 ) in the context of higher education. Mentioned terms are transdisciplinary fields considering many disciplines such as economics, information technology, philosophy, communication studies, pedagogy, psychology and others. The focus of this article will be on pedagogical and educational aspects.

To review the essence of transformative digital learning using dictionaries overview terms analyses approach has been applied, by separately defining: transformation, digital and learning. Basing on the definition's analyses stated in the vocabularies further research has been applied using the basic three concepts: digital learning; digital transformation; transformative learning.

\section{Results and Discussions}

In order to explain the meaning of transformative digital learning in the context of higher education it is necessary to divide the term into three separate concepts digital, transformative and learning. As there is no exact definition of transformative digital learning. The aim of this paper to review the literature about the topic and by analysing different explanations and approaches to formulate the definition of transformative digital learning. Three mentioned concepts were characterized in the terms of vocabulary explanations. Based on the definitions from Merriam Webster Thesaurus, Cambridge Dictionary and Pedagogical dictionary (Konjajeva, Pavlova, 2012; Uvarov et al., 2019) summary analyses presented in Table 1 .

Table 1

Transformative digital learning - dictionaries overview

\begin{tabular}{|c|c|c|c|c|}
\hline & $\begin{array}{l}\text { Merriam Webster } \\
\text { Thesaurus }\end{array}$ & Cambridge Dictionary & Pedagogical Dictionary & $\begin{array}{c}\text { Terms of TDL } \\
\text { definition } \\
\text { formation }\end{array}$ \\
\hline 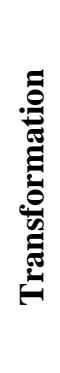 & $\begin{array}{l}\text { - a marked change in form, } \\
\text { appearance or use }\end{array}$ & $\begin{array}{l}\text { - a major change to } \\
\text { something or } \\
\text { someone, especially } \\
\text { in a way that makes } \\
\text { it or them better }\end{array}$ & \multirow{2}{*}{$\begin{array}{l}\text { Digital transformation - } \\
\text { updating of planned } \\
\text { educational results, } \\
\text { content, methods and } \\
\text { organizational forms of } \\
\text { academic work, as well } \\
\text { as evaluation of the } \\
\text { achieved results in a } \\
\text { quick evolving digital - } \\
\text { educational environment } \\
\text { with aim to improve the } \\
\text { individual educational } \\
\text { results of each student. }\end{array}$} & $\begin{array}{l}\text { Change or update } \\
\text { of educational } \\
\text { results, content, } \\
\text { methods and } \\
\text { organizational form } \\
\text { adopting them to } \\
\text { the quickly } \\
\text { evolving digital } \\
\text { environment }\end{array}$ \\
\hline$\stackrel{\bar{T}}{\stackrel{500}{6}}$ & $\begin{array}{l}\text { - (of signals or data) } \\
\text { expressed as series of the } \\
\text { digits } 0 \text { and } 1\end{array}$ & $\begin{array}{l}\text { - regarding or storing } \\
\text { information as series } \\
\text { of the numbers } 1 \text { or } \\
0, \text { to show that a } \\
\text { signal is present or } \\
\text { absent; using or } \\
\text { relating to digital } \\
\text { signals and computer } \\
\text { technology; } \\
\text { - showing information } \\
\text { in the form of an } \\
\text { electronic image; }\end{array}$ & & $\begin{array}{l}\text { Usage of computer } \\
\text { technology } \\
\text { digitalizing } \\
\text { educational process }\end{array}$ \\
\hline
\end{tabular}




\begin{tabular}{|c|c|c|c|c|}
\hline & $\begin{array}{l}\text { Merriam Webster } \\
\text { Thesaurus }\end{array}$ & Cambridge Dictionary & Pedagogical Dictionary & $\begin{array}{c}\text { Terms of TDL } \\
\text { definition } \\
\text { formation }\end{array}$ \\
\hline 芳 & $\begin{array}{l}\text { - the act or experience of } \\
\text { one that learns; } \\
\text { - knowledge or skill } \\
\text { acquired by instruction or } \\
\text { study; } \\
\text { - modification of a } \\
\text { behavioral tendency by } \\
\text { experience; } \\
\text { - the activity or process of } \\
\text { gaining knowledge or skill } \\
\text { by studying, practicing, } \\
\text { being taught, or } \\
\text { experiencing something; } \\
\text { - the activity of someone } \\
\text { who learns; } \\
\text { - knowledge or skill gained } \\
\text { from learning. }\end{array}$ & $\begin{array}{l}\text { - the activity of } \\
\text { obtaining knowledge }\end{array}$ & $\begin{array}{l}\text { - the process of transfer } \\
\text { and active assimilation } \\
\text { of knowledge, skills } \\
\text { and abilities, as well as } \\
\text { ways of meaningful, } \\
\text { cognitive activity; } \\
\text { - the process of } \\
\text { introducing the student } \\
\text { to knowledge, } \\
\text { assistance in mastering } \\
\text { skills, which are } \\
\text { purposefully and } \\
\text { systematically carried } \\
\text { out by lecturers or other } \\
\text { specially trained } \\
\text { specialists, the key way } \\
\text { to get an education. }\end{array}$ & $\begin{array}{l}\text { The process } \\
\text { introducing, } \\
\text { transferring and } \\
\text { activating } \\
\text { knowledge, skills } \\
\text { and abilities as well } \\
\text { as ways of } \\
\text { meaningful, } \\
\text { cognitive activity }\end{array}$ \\
\hline
\end{tabular}

Sources: (Merriam Webster Thesaurus, 2019); (Cambridge Dictionary, 2019); Pedagogical Dictionary

(Uvarov et al., 2019); (Konjajeva, Pavlova, 2012).

To summarize the described vocabulary definitions there are common features in each concept: transformation, digital and learning. However, there no separate definition of word digital in the context of education, only in connection with transformation. Because of this the definition of digital transformation in the context of higher education has been analysed.

Among the terms indicated in Table 1 for definition of TDL the basic emphasize is on change and update of planned education results for each individual in context of transformation; quick evolving digital education environment by introducing, transferring and activating knowledge, skills and abilities to meaningful and cognitive ones. For further research another concept method has been used, separately analysing the following: digital learning, digital transformation and transformative learning.

Digital learning (DL) can be a driver for skills development to potentiate organizations digital transformation (Sousa, Rocha, 2019a). The definition given by E. Kyndt, F. Dochy, M. Michielsen, B. Moeyaert describes DL as an unplanned and implicit process with unpredictable results using different types of technological devices such as smartphones, tablets, computers (Kyndt et al., 2009). According to A.C. Gonḉalves, M.J. Sousa, R. Cruz there are two possible ways of digital learning:

1. spontaneous, unconscious process in order to prepare the student for critical thinking and complex problems solving, for collaborative work and effective communication, independent learning;

2. specially planned process by combination of different learning activities like a search of information or watching special educational videos with the goal to understand better the issue and acquire more knowledge about it (Gonçalves, Sousa, Cruz, 2017). L. Davis, on the other hand, indicates that DL is an technology-enhanced instructional practice that also includes blended, flipped and personalized learning or other strategies using digital tools. A DL strategy may be a combination of different activities such as adaptive learning; badging and gamification; blended learning; classroom technologies; e-textbooks; learning analytics; learning objects; mobile and personalized learning; online learning (or e-learning); open educational resources; technology-enhanced teaching and learning; virtual reality; augmented reality, artificial intelligent; robotics (Davis, 2019).

To sum up, it can be stated that DL can be either spontaneous, unconscious or planned and organized process, using a broad range of technology- enhanced educational strategies, including blended, flipped, online and personalized learning. 
The digital transformation (DT) of education is an inevitable process for the change of educational content, methods and organizational forms, which takes place in a rapidly developing digital educational environment and is aimed to solve socio-economic development problems of the country in the conditions of the fourth industrial revolution and digital economies (Uvarov et al., 2019).

The world in general, and organizations and institutions in particular, is changing faster than ever. DT takes organizations to the next level. It is a modern phenomenon affecting all spheres of life, public administration and public services (Mergel, Edelmann, Haug, 2019), business and entrepreneurship (Tekic, Koroteev, 2019), other organizations (Sousa, Rocha, 2019b) and educational institutions (Filho et al., 2018).

Besides this according to network readiness index - a comprehensive indicator showing the level of information and communication technologies development in the world, offered by World Economic Forum - Latvia ranked $32^{\text {nd }}$ in the world (Baller, Dutta, Lanvin, 2016).

In order to explain the base of any DT the focus on digitalization providers was made. Microsoft the leading global vendor of computer software, hardware, mobile and gaming systems, and cloud services indicates the basic concept of DT is not just a basic upgrade of hardware or software, but it is a physical change (Uvarov et al., 2019) and philosophical transformation (Tekic, Koroteev, 2019) to meet the growing demands of educational institutions and create the overall connection in a learning environment, where technology, services and security are provided for collaborative, interactive and personalized learning experiences creation (Microsoft, 2019).

One more American leading corporation Alcatel Lucent offered their concept of DT, indicating that it starts with a strategy. A clearly defined strategy that leverages opportunities presented by the new technology while meeting the objectives of the stakeholders. The following four steps necessary to develop a DT strategy for education:

1. to connect everything - high capacity communication network creation;

2. deploy analytics to automate, understand and save money, necessity to use real life, real-time data to drive strategic initiatives that improve performance, upgrades and infrastructure decisions.

3. to update business models, software and on-demand services, making them cheaper, more flexible and simpler to manage;

4. to create single platform as the basic foundation of the network and communications infrastructure for the institution (Figure 1).

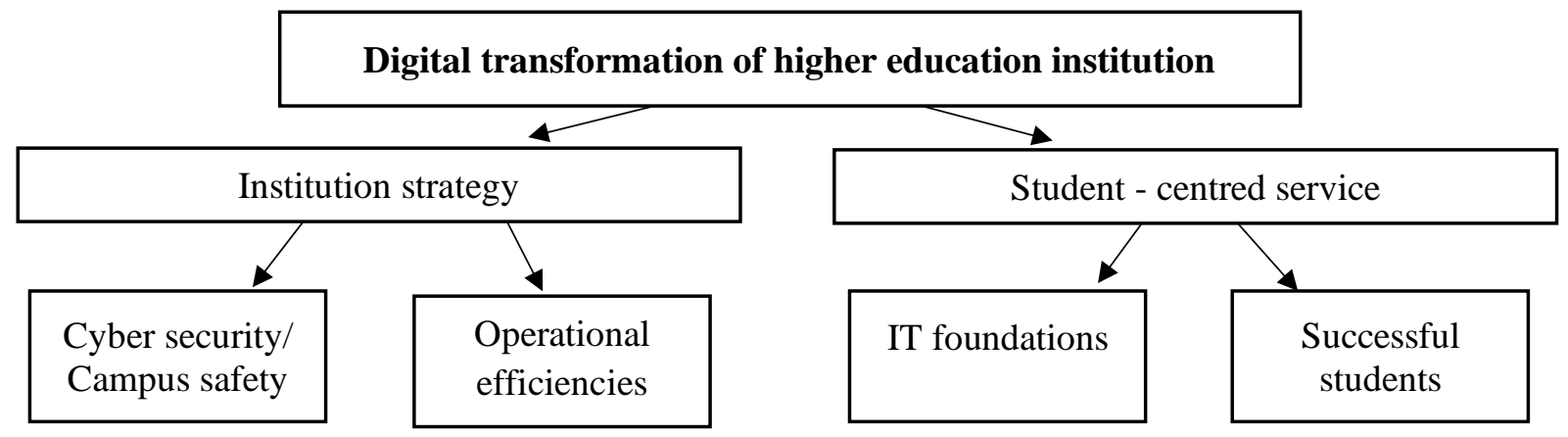

Figure 1. Digital transformation of higher educational institution (Alcatel-Lucent, 2019).

According to Figure 1 the key factors of Alcatel-Lucent strategy were indicated as strategy and student - centred service. In order to provide the IT foundations, the successful work of student, cyber security and safety and operational effectiveness, the following components are needed: network infrastructure, mobility, collaborative working rainbow, Internet of Things and solved security issue. So, DT of higher education is creating a world of difference by rethinking the used digital tools for new levels of collaboration, innovation and endless learning possibilities (Alcatel-Lucent, 2019).

Some companies see DT as a way to optimize processes and cut costs, while others view it as an opportunity to create new value by offering something new (Tekic, Koroteev, 2019), while in the terms of higher education DT has its effect on two main business parts:

1. transformation in services that focuses on creating new education products and transforming existing products into digital ones (like video lectures, digital texts, quizzes and digital means for communication between students and teachers); 
2. transformation in operations that requires a digitalization of all the common operations offering by educational institutions like students' admission, registration for programs and courses, examination, program development, student' quality assurance and also study planning, facility management, teacher allocation, scheduling (Jackson, 2019).

Microsoft offers their definition of DT as the use of new, fast and frequently changing digital technology to solve_problems often utilizing cloud computing, reducing reliance on user owned hardware_but increasing reliance on subscription-based cloud services (Microsoft, 2019).

Thus, DT in the context of higher education is observed within two directions: strategy of higher education institution and student-centred service, by changing the educational content, methods, results and organizational forms. DT is must-have new paradigm that takes organizations to the next level of development. Besides this DT an ecosystem that combines technology, offered services and security to ensure collaborative, interactive, online and personalizes learning.

Transformative learning (TL) has been described in the J. Mezirow's Transformation Theory. According to which, TL is learning that occurs when an adult engages in activities that cause or allow them to see a different worldview from their own. Afterwards adults work to integrate the implications of that different worldview into their own worldview, thereby enlarging it. This process of changing to person's worldview and the enlarging of it is called transformative by J. Mezirow (as cited in Taylor, 2007). The following four processes of learning had been indicated by J. Mezirow: to elaborate the existing point of view $\rightarrow$ to establish new points of view $\rightarrow$ to transform our point of view $\rightarrow$ to transform ethnocentric habit of mind (Mezirow, 1999).

The basic aim of the learning process was to transform the existing point of view through new knowledge or even to influence ethnocentric habit of mind. The following key elements of transformative learning were named by J. Mezirow: disorienting dilemma; critical reflection; rational discourse. In 1999 J. Mezirow has added seven more elements for the TL (total ten) and explained the existed ones:

- a disorienting dilemma - as significant stimulus to undergo meaning perspective transformation;

- $\quad$ self - examination with different feelings such as fear, anger, guilt, shame;

- a critical assessment of assumptions;

- recognition that one's discontent and the process of transformation are shared;

- exploration of options for new roles, relationships and actions;

- planning a course of action;

- acquiring knowledge and skills for implementing one's plan;

- provisional trying of new roles;

- building competences and self-confidence in new roles and relationships.

- a reintegration into one's life dictating by one's new perspectives (Mezirow, 2003).

Much of the research in TL, learners acquire in the context of higher education institutions. This is type of deep learning involving building social relationships and requires more changes that foster a culture of learning, support, reflection and meaningful communication (Henderson, 2002) see in Table 2.

It is important to note that initially created by J. Mezirow TL theory by changing person's worldview, enlarging and transforming it, has been adopted within the time being by adding to the basic concept the following opportunities for the students: critical thinking; relating to others transformative process; acting on new perspectives. Motivated students are able to transfer the acquired knowledge to new and unexpected situations. 
Transformative learning - theories overview

\begin{tabular}{|c|c|c|c|c|c|}
\hline & $\begin{array}{c}\text { Theory of } \\
\text { R.B. Boyd, J.G. } \\
\text { Myers }\end{array}$ & $\begin{array}{l}\text { Theory of } \\
\text { P. Cranton }\end{array}$ & $\begin{array}{l}\text { Theory of } \\
\text { J. Dirkx }\end{array}$ & $\begin{array}{c}\text { Theory of } \\
\text { P. Howie, } \\
\text { R.G. Bagnall }\end{array}$ & $\begin{array}{l}\text { Theory of } \\
\text { M. Christie, } \\
\text { A. Robertson, } \\
\text { M.D. Carey }\end{array}$ \\
\hline 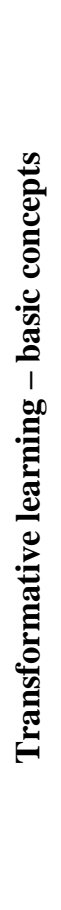 & $\begin{array}{l}\text { three dimensions } \\
\text { of "perspective } \\
\text { transformation": } \\
\text { - psychological by } \\
\text { changing the } \\
\text { understanding of } \\
\text { the self; } \\
\text { - convictional by } \\
\text { revision of belief } \\
\text { systems; } \\
\text { - behavioral by } \\
\text { changes in } \\
\text { lifestyle }\end{array}$ & $\begin{array}{l}\text { the role of learner } \\
\text { - the educator } \\
\text { becomes a } \\
\text { facilitator; the } \\
\text { goal of learning } \\
\text { is for learners to } \\
\text { construct } \\
\text { knowledge about } \\
\text { themselves, } \\
\text { others, and } \\
\text { social norm. }\end{array}$ & $\begin{array}{l}\text { the expansion of } \\
\text { consciousness } \\
\text { through the } \\
\text { transformation of } \\
\text { basic worldview } \\
\text { and specific } \\
\text { capacities of the } \\
\text { self through } \\
\text { appreciatively } \\
\text { accessing and } \\
\text { receiving the } \\
\text { symbolic contents } \\
\text { of the } \\
\text { unconscious and } \\
\text { critically } \\
\text { analysing } \\
\text { underlying } \\
\text { premises }\end{array}$ & $\begin{array}{l}\text { the opportunities: } \\
\text { - for critical } \\
\text { thinking, by } \\
\text { providing } \\
\text { content that } \\
\text { introduces new } \\
\text { ideas; } \\
\text { - to relate to } \\
\text { others going } \\
\text { through the same } \\
\text { transformative } \\
\text { process, being } \\
\text { inspired by the } \\
\text { changes friends } \\
\text { and } \\
\text { acquaintances } \\
\text { make; } \\
\text { - to act on new } \\
\text { perspectives, by } \\
\text { acting on their } \\
\text { new found } \\
\text { beliefs }\end{array}$ & $\begin{array}{l}\text { - motivated } \\
\text { students will } \\
\text { have the chance } \\
\text { to become } \\
\text { lifelong learners } \\
\text { capable of acting } \\
\text { successfully in a } \\
\text { rapidly changing } \\
\text { world; } \\
\text { - critically aware } \\
\text { students will be } \\
\text { able to transfer } \\
\text { the acquired } \\
\text { knowledge to } \\
\text { new and } \\
\text { unexpected } \\
\text { situations, even } \\
\text { changing their } \\
\text { beliefs; } \\
\text { re-assess the } \\
\text { validity of } \\
\text { learning; }\end{array}$ \\
\hline
\end{tabular}

Source: (Boyd, Myers, 1988); (Cranton, 2009); (Dirkx, 1997); (Howie, Bagnall, 2013); (Christie et al., 2015).

Definition of Transformative digital learning (TDL) - summing up described three concepts of TDL as digital learning, digital transformation and transformative learning the following basic categories of TDL were explained: digital technologies (digital learning), strategy (digital transformation) and personalized experience or new perspectives (transformative learning). Technology is an essential component of learning and educational process nowadays. With digital applications, tools, instruments and resources, students can create content, interact with experts, collaborate with peers and participate in simulation activities and work. Personalized and individualized experiences put students at the centre of learning and empowers students to take control of their own learning through flexibility and choice. Besides the technology presence in pedagogical process the transformative learning is the necessity as well (Žogla, Prudnikova, Mykhailenko, 2019).

By indicating the new role of technologies in education and changing the pedagogy accordingly the following aspects should be included:

1. technology to be presented in pedagogical processes with crucial restructuring of learning environments;

2. professional philosophy and capacity for thoughtful, reflective and flexible activity in assisting learners for educators;

3. incorporated effective technologies into a variety of methodologies when methods of learning are chosen or agreed upon by learners, the role of learner is important;

4. personal empowering of student and learner due to digital competence allowing for transformed mutual relations with deep, strategic and personalized learning in educator-student collaborative teams (Mykhailenko et al., 2018).

Summing up, the undergoing transition towards better understanding and learning with digital technologies in acquiring higher level competencies in order to achieve rich intellectual properties to 
identify the themes and values of emerging importance, where professional philosophy of educators and personal empowering of students take important role.

\section{Conclusion}

The concepts allowed to state the definition of transformative digital learning - the process of individualized, lifelong spontaneous or planned technology - enhanced learning, changing and updating of educational results, content, methods and organizational form adopting them to the quickly evolving digital environment, including physical and philosophical change or transformation to meet growing demands of learners to achieve rich intellectual property by defining new perspectives and adopting personal worldview accordingly value- created learning.

TDL is associated with qualitative changes in educational work, especially for higher education and adults learning. It is necessary in order to form the ability of each member of society to live and work productively in a changing economy, to continue their education throughout all life. The essence of this change is the use of rapidly developing digital technologies for a consistent transition to a personalized result-oriented educational process. The digitalization and the digital transformation of education stimulated by it increasingly influence the development of the education system including the learning process of individuals, poses new challenges and tasks.

\section{Acknowledgment}

This article is part of the Applied Research "Implementation of Transformative Digital Teaching in Doctoral Program of pedagogical Science in Latvia"(DocTDLL) Izp-2018/2-0180.

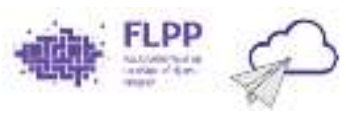

\section{Bibliography}

1. Alcatel-Lucent. (2019). Why digital transformation of Education. Retrieved from https://www.alenterprise.com/-/media/assets/internet/documents/digital-transformation-faq-en.pdf

2. Baller S., Dutta S., Lanvin B. (Eds.). (2016). Global Information Technology Report. Geneva: World Economic Forum doi: 10.13140/RG.2.2.26157.90088

3. Boyd R.D., Myers J.G. (1988). Transformative Education. International Journal of Lifelong Education, 7(4), 261-284. doi: 10.1080/0260137880070403

4. Cambridge Dictionary. (2019). Retrieved from https://dictionary.cambridge.org

5. Christie M., Carey M.D., Robertson A., Grainger P. (2015). Putting transformative learning theory into practice. Australian Journal of Adult Learning, 55(1), 9-30. Retrieved from https://search.informit.com.au/documentSummary;dn=069076554869878;res=IELHSS

6. Cranton P. (2009). Understanding and Promoting Transformative Learning: A Guide for Educators of Adults. Canadian Journal of University Continuing Education, 35(1), 67-69. Retrieved from https://ejournals.library.ualberta.ca/index.php/cjuce-rcepu/article/download/8516/6874

7. Davis L. (2019). Digital Learning What to Know in 2019. Retrieved from https://www.schoology.com/blog/digital-learning-what-know-2019

8. Dirkx J. (1997). Nurturing soul in adult learning. New Direction for Adult \& Continuing Education, 1997(74), 79-88. doi: 10.1002/ace.7409

9. Filho L.W., Raath S., Lazzarini B., Vargas V.R., de Souza L., Anholon R., Quelhas O.L.G., Haddad R., Klavins M., Orlovic V.L. (2018). The Role of Transformation in Learning and Education for Sustainability. Journal of Cleaner Production, 199(20), 286-295. doi: 10.1016/j.jclepro.2018.07.017

10. Gonḉalves A.C., Sousa M.J., Cruz R. (2017). Designing Higher Education Digital Course to Boost Entrepreneurship Competencies. In L.G. Chova, A.L. Martinez, I.C. Torres (Eds.), The Proceedings of the International Conference on Education and New Learning Technologies, 9. Barcelona: IATED, 3322-3329. Retrieved from https://library.iated.org/view/GONCALVES2017DES

11. Henderson J. (2002). Transformative Learning as a Condition for Transformational Change in Organizations. Human Resource Development Review, 1(2), 186-214.

doi: $10.1177 / 15384302001002004$ 
12. Howie P., Bagnall R. (2013). A Beautiful Metaphor: Transformative Learning Theory. International Journal of Lifelong Education, 32(6), 816-836. doi: 10.1080/02601370.2013.817486

13. Jackson N.C. (2019). Managing for competency with innovation charge in higher education: Examining the pitfalls and pivots of digital transformation. Business Horizons, 62(6), 761-772. doi: 10.1016/j.bushor.2019.08.002

14. Jauno mācību gadu pasludina par "Tehnoloǵiju gadu" [The new school year is proclaimed as "Technology Year"]. (2019). Riga: Izglìīības un zinātnes ministrija. Retrieved from https://www.izm.gov.lv/lv/aktualitates/3629-tehnologiju-gada (in Latvian)

15. Konjajeva J., Pavlova L. (2012). Short dictionary of pedagogical concepts. Cheljabinsk. CGPI. Retrieved from https://docplayer.ru/39025170-E-a-konyaeva-1-n-pavlova-kratkiy-slovarpedagogicheskih-ponyatiy.html

16. Kyndt E., Dochy F., Michielsen M., Moeyaert B. (2009). Employee retention: Organisational and Personal Perspectives. Vocations and Learning, 2(3), 199-215. doi: 10.1007/s12186-009-9024-7

17. Mergel I., Edelmann N., Haug N. (2019). Defining Digital Transformation: Results from Expert Interviews. Government Information Quarterly, 36(4), article 101390. doi: 10.1016/j.giq.2019.06.002

18. Merriam-Webster Thesaurus. (2019). Retrieved from https://www.merriamwebster.com/thesaurus/transformation

19. Mezirow J. (1999). Transformation theory - postmodern issues. In the Proceedings of the Conference on Adult Education Research Conference. Retrieved from https://newprairiepress.org/aerc/1999/papers/29/

20. Mezirow J. (2003). Transformative Learning as Discourse. Journal of Transformative Education, 1(1), 58-63. doi: 10.1177/1541344603252172

21. Microsoft. (2019). Focus on four areas to unlock value. Retrieved from https://www.microsoft.com/en-us/enterprise/digital-transformation

22. Mykhailenko O., Blayone T., Žogla I., Lubkina V. (2018). Using activity theory for modelling transformative digital learning. In V. Lubkina, A. Indriksons, S. Usca (Eds.), The Proceedings of the International Scientific and Practical Conference Environment, Technology, Resources, 2, 222-227. Rezekne. doi: 10.17770/etr2019vol2.4044

23. Sousa M.J., Rocha Á. (2019a). Digital learning: Developing skills for digital transformation of organizations. Future Generation Computer Systems, 91, 327-334.

doi: 10.1016/j.future.2018.08.048

24. Sousa M.J., Rocha Á. (2019b). Skills for disruptive digital business. Journal of Business Research, 94, 257-263. doi: 10.1016/j.jbusres.2017.12.051

25. Taylor E.W. (2007). An update of transformative learning theory: a critical review of the empirical research (1999-2005). Journal of lifelong education, 26(2), 173-191. doi: 10.1080/02601370701219475

26. Tekic Z., Koroteev D. (2019). From disruptively digital to proudly analogue: A holistic typology of digital transformation strategies. Business Horizons, 62(6), 683-693. doi: 10.1016/j.bushor.2019.07.002

27. Uvarov A., Van S., Kan C., Su X., Cao P., Czjan S., Chan J., Chzhu S. (2019). Problemi i Perspektivi Cifrovoj Transformaciji Obrazovanija v Rossii i Kitae [Digital Transformation of Education in Russia and China Problems and Perspectives]. Moscow: Highschool of Economics. Retrieved from https://aiedu.hse.ru/mirror/pubs/share/308201188 (in Russian)

28. Visvizi A., Lytras M.D., Daniela L. (Eds.). (2018). The Future of Innovation and Technology in Education: Policies and Practices for Teaching and Learning Excellence. UK, North America, Japan, India, Malasia, China: Emerald Publishing.

29. Žogla I., Prudnikova I., Mykhailenko O. (2019). Pedagogical Assumptions of Transformative Digital Model for Social Change. In V. Lubkina, A. Indriksons, S. Usca (Eds.), The Proceedings of the International Scientific Conference Society. Integration. Education, 1. Rezekne: Rezekne Academy of Technologies, 645-656. doi: 10.17770/sie2019vol1.3881 